\title{
WHY WORLD EXPORTS ARE SO SUSCEPTIBLE TO THE ECONOMIC CRISIS --THE PREVAILING "EXPORT OVERSHOOTING" PHENOMENON
}

\author{
Bih Jane Liu \\ Working Paper 16837 \\ http://www.nber.org/papers/w16837 \\ NATIONAL BUREAU OF ECONOMIC RESEARCH \\ 1050 Massachusetts Avenue \\ Cambridge, MA 02138 \\ February 2011
}

The author would like to thank Yalin Alice Chiang for her excellent research assistance. The author would also like to thank the participants of 21st Annual East Asian Seminar on Economics (A Pacific Rim Perspective on the Financial Crisis, June 25-26, 2010) for their very helpful suggestions. The views expressed herein are those of the author and do not necessarily reflect the views of the National Bureau of Economic Research.

NBER working papers are circulated for discussion and comment purposes. They have not been peerreviewed or been subject to the review by the NBER Board of Directors that accompanies official NBER publications.

(C) 2011 by Bih Jane Liu. All rights reserved. Short sections of text, not to exceed two paragraphs, may be quoted without explicit permission provided that full credit, including $\bigcirc$ notice, is given to the source. 
Why World Exports are so Susceptible to the Economic Crisis--The Prevailing "Export Overshooting" Phenomenon

Bih Jane Liu

NBER Working Paper No. 16837

February 2011

JEL No. F1,F14

\begin{abstract}
This paper provides some evidence of the "export overshooting" phenomenon, i.e., the unusually large deviation of exports from their long-run level. We study the export trends of a sample of 37 countries including both OECD and non-OECD countries over the period of 1994-2009. We find that exports overshot their equilibrium value during economic crises and that the tendency to overshoot was a worldwide phenomenon. The bullwhip effect was the driving force behind such a phenomenon. Moreover, the extent of export overshooting was increasing in more recent crisis, which can be attributed to an increase in cross-border vertical specialization over time.
\end{abstract}

\author{
Bih Jane Liu \\ Chung-Hua Institution for Economic Research \\ 75 Chang-Hsing Street \\ Taipei 106, Taiwan \\ bjliu@cier.edu.tw \\ and Department of Economics \\ National Taiwan University \\ 21 Hsu-Chow Road \\ Taipei 100, Taiwan \\ bjliu@ntu.edu.tw
}




\section{Introduction}

In the years leading up to the summer of 2007 when the U.S. subprime crisis began to unfold, the world saw a period of relative calm and prosperity after the recovery from the dot-com bubble-burst in the early 2000s. While the major industrialized nations grew at a modest pace of 1 to 3 percent per annum, the rise of the BRIC and other emerging markets gave great impetus to the world's economic progress and spurred high growth in world trade. But the subprime loan problem gave way quickly to a broad global crisis marked by slowing economies and dried-up liquidity with unprecedented reach. The scope and devastating impacts of the global financial crisis were greater than anyone had anticipated. Like a game of dominos, the financial crisis started in the United States and spread to the rest of the world. It first lacerated the world's financial systems, then jolted and knocked out the real economy. No country was immune to it. Not the "Wealthy Country Club" with member countries such as the United States, Germany, and Japan. Not the usually resilient East Asian NICs. Not even the up-and-coming powerful BRIC group. Among all these, countries with a strong export orientation and opened up most to the world, especially Japan and the East Asian NICs, were hit the hardest.

Unlike the 2008 global financial crisis where the impacts were industry- and world-wide, the internet crisis, a speculative bubble covering roughly the period 1998-2001, originated from the accelerated growth in internet related industries and therefore tended to be sector-specific in nature. Because of the "get-big-fast" strategy adopted by the new internet-based companies and the market confidence on the profitable future of these companies, the internet bubble saw rapid run-ups in market valuations on these companies (Valliere and Peterson, 2004). When the bubble burst in 2000, it was followed by an equally rapid collapse of the markets and led to 
bankruptcy of many internet firms and huge losses in stock markets. The United States, Canada, Asia and Europe all suffered from the sharp drop in stock prices during 2000 and 2002. Countries with a heavy reliance on the exports of high-tech products such as Japan, South Korea and Taiwan saw the global demand for ICT products slowing in a weak economic outlook.

The Asian crisis was somewhat different. It was triggered by the financial crisis in a relatively small country (Thailand), where speculation caused funds to drain out of Thai currency and stock market. ${ }^{1}$ The crisis was then spread to a wide set of economies. It crippled East Asian economies throughout the following two years, which surprised many due to its rapidity and pervasiveness (Yang \& Lim, 2004). By mid-1998, most of the economies in Asia were in a crisis of a similar nature. The turbulence had also spread beyond the Asian region. Countries such as Russia and Brazil showed signs of contagion in 1998; even the U.S. suffered from the collapse of some hedge funds, ${ }^{2}$ which was once described as the most serious financial situation since the post-war-period by the Clinton administration. However, because of the intervention by the US Federal Reserve Board, the contagion effects were rather limited in scope.

The above three crises, although different in nature, had all caused the world economy to fall. But the extent and the scope of the impacts varied across different crises. For the Asian financial crisis, the non-OECD countries, especially Asia, were the most negatively affected (Table 1). The GDP growth rates of NICs and ASEAN slowed down in 1998 and turned negative in 1999. In the 2001 internet crisis, on the other hand, the OECD countries (mainly the advanced industrialized countries) in

\footnotetext{
${ }^{1}$ This is unusual as most of the financial crisis runs from large countries to smaller ones (Goldstein, 1998).

${ }^{2}$ The U.S. suffered from the $\$ 3$ billion collapse of the US hedge fund of Long Term Capital Management.
} 
which bank lending was biased toward internet related industries were hit harder than non-OECD countries. Despite the economic downturn in the two crises, the world still grew upward but only at a slow motion. The 2008 global financial crisis, however, was quite different; the world GDP growth rate had already turned negative in 2009, a year after the crisis broke out in 2008.

The three crises also caused the world exports to contract. Figure 1 and Figure 2 display the monthly export growth rates for the 27 OECD countries (OECD27) and the 6 Asian countries (Asia6) during 1995 to 2009, respectively. ${ }^{3}$ As the figures show, among the three crises, the 2008 crisis had the most severe impact on the world trade. The exports began to fall in the second half of 2008 and quickly rebounded towards the end of the first half of 2009, forming a narrow V-shaped pattern of growth trajectory. The similar V-shaped pattern was also observed during the internet crisis around 2001 and in the Asian financial crisis, where in the latter the V-shaped export growth pattern seems to be limited to the Asian region. Moreover, world exports had become more volatile with each shock; this is made clear with the V-shaped pattern appearing much deeper and narrower in the more recent crisis.

It is worth noting that during the economic downturns discussed above, the contraction in world exports was far greater than that of world GDP, as revealed in Table 1 and Table 2. In 1998 and 2001, while real world GDP still grew positively at $2.35 \%$ and $1.65 \%$, respectively, the growth of total exports for the countries such as Indonesia, Taiwan, the United Kingdom, and the United States had already turned negative. The overall export performance was much worse in the recent economic

${ }^{3}$ OECD27 refers to the 27 OECD countries, i.e., Australia, Austria, Belgium, Canada, Czech Republic, Denmark, Finland, France, Germany, Greece, Hungary, Iceland, Ireland, Italy, Mexico, Netherlands, New Zealand, Norway, Poland, Portugal, Slovenia, Spain, Sweden, Switzerland, Turkey, United Kingdom and United States. Asia6 includes China, India, Indonesia, Japan, Korea and Taiwan; other Asian countries such as Malaysia, Philippines, Singapore, and Thailand are not included because some of the monthly data are not available. 
downturn, with almost all countries studied here experiencing negative export growth. The total exports for countries such as Germany, Italy, Japan, and Taiwan, even shrank at an astounding rate of more than 20\% a year after the crisis broke out in 2008. Meanwhile real world GDP suffered only a mild decline and growth slowed down to $-1.86 \%$ in 2009.

A number of papers have identified that fluctuations in exports are highly correlated with the changes in worldwide demand, effective exchange rates, the volatility of exchange rates (see for example, Boug and Fagereng, 2010; Sapir and Sekka, 1995), and FDI (e.g., Zhang and Song, 2000). These determinants (hereafter referred to as the fundamental factors) have been shown to govern adequately the behavior of the export growth performance of a country in the long run. The fact that the decline in world exports was much greater than the decline in world GDP during the economic crises suggests that the force causing exports to deviate from their long-run trend may have been further magnified by some other factors not accounted for in the literature. In other words, the surprisingly large declines in exports may not be predicted fully by the conventional relationships linking exports to the fundamental factors. Such an unusually large deviation of exports from their long-run level is referred to as the "export overshooting phenomenon" hereafter, the main subject of this study.

Based on what we have observed, several testing hypotheses are formulated in the paper. Specifically, we look for evidence that addresses the "export overshooting phenomenon” during times of economic duress. We also offer some explanations for why world exports are so susceptible to economic crises.

We investigate the export patterns of 37 countries, including 10 Asian countries 
and 27 OECD countries. ${ }^{4}$ The time span being studied covers the period from 1994 to 2009, in which the world had experienced three economic crises, i.e., the Asian financial crisis in 1997, the internet bubble bursting in 2001, and the global financial crisis in 2008. These crises, though different in nature and origin, had all led to similar V-shaped contraction patterns of world export. It is therefore interesting to examine how exports adjusted to these economic shocks and discuss some of the factors that may have caused exports to overshoot in each of these downturns.

The structure of the paper is as follows. We begin with a comparison in terms of causes and economic impacts of the three economic crises in Section 2. We then derive several testable hypotheses based on the revealed trends and patterns of exports during the crisis periods. These hypotheses are then tested in Section 3 using an error correction panel regression model. In a dynamic setting, we show how and why the response of exports to adverse external shocks may vary across different groups of countries and industries. Some explanations as to why, when facing economic crises, exports overshot its long-run trend are provided in Section 5. The last section summarizes the findings and offers conclusions.

\section{Impact of Economic Crisis on Exports}

Although the three economic crises were triggered by different events such as the capital flight out of East Asia, the internet bubble busting, and the subprime crisis, they did share some features in common. That is, they all experienced financial contagion and had effects on both financial and real sectors.

\footnotetext{
${ }^{4}$ The 10 Asian countries are China, India, Indonesia, Japan, Korea, Malaysia, Philippines, Singapore, Thailand, and Taiwan. In 2008, the export share of 10 Asian countries and 27 OECD countries accounts for about $80 \%$ of the world's total exports. An earlier version of this paper by Liu (2010) which studies a smaller sample (9 Asian countries, the U.S. and the EU) and for a shorter time span (2000-2009) will be included in the book "The Impact of the Economic Crisis on East Asia” edited by Daigee Shaw and Bih Jane Liu, Edward Elgar Publishing LTD., London (forthcoming).
} 
Financial crisis often starts as a series of malfunctions in the financial markets, leading to credit, exchange, and liquidity crises in a country or a region. Asian financial crisis is no exception. Due to the rapid growth of real GDP, the ASEAN countries, mainly Indonesia, Malaysia, the Philippines and Thailand, experienced credit boom in the early 1990s. The overextension of credit, which concentrated on the areas of real estate and equities, left the Southeast Asian economies vulnerable to a shift in credit and cyclical conditions (Goldstein, 1998). As a result, almost all Asian currencies confronted various degree of speculative attack after the occurrence of the Thai baht crisis in July $1997 .^{5}$ When international investors rushed their capital out of the Asian markets, the asset prices and currencies fell almost simultaneously. This had led to acute economic recession and export contractions in several Asian countries. The preponderance of intra-Asia trade link (59.1\% in 1997), which had been an important driving force behind the rapid regional growth in the first half of the 1990s, became a liability as they provided a perfect channel for the contagion to spread swiftly throughout Asia (Das, 1999). After the crisis, a large number of Asian banks were weighed down because of having massive bad debts and could not make further loans as they were not able to meet the 8 percent capital-adequacy ratio stipulated by the IMF. Trade credit therefore became one of the biggest supply-side constraints for the exporters in Asia. Meanwhile, the extraordinarily large extent of depreciation for many of the Asian currencies ${ }^{6}$ did not help improve export performance as the traditional wisdom suggests. This is because the import content of the Asian exports was inordinately high, especially in industries such as electronics and autos. But the volatility of

\footnotetext{
${ }^{5}$ The fact that quite a few Asian countries such as Indonesia, Philippines, and Malaysia, had weakness similar to Thailand may help explain this contagion: large currency account deficits, deteriorating quality of investment, appreciating real exchange rates, a marked export slowdown in 1996, and overexpansion in certain key industries. Even Japan and Korea also faced with massive bad loans and serious weakness in its financial sector and in prudential oversight of banks (Goldstein, 1998).

${ }^{6}$ For example, between June 1997 and August 1998 the Indonesian rupiah, Malaysian ringgit and Thai baht depreciated by $82.9 \%, 40.9 \%$ and $39.7 \%$ against the US dollar, respectively.
} 
exchange rates had been shown to be a significant factor negatively affecting exports of the Asian economies during the Asian financial crisis. The exports of countries outside Asia, however, were less affected by the Asian crisis due possibly to the relatively smaller financial contagion and trade linkages and hence small GDP contraction as shown in Table 1 and 2. For example, although the U.S. suffered from the collapse of hedge funds, the bailout intervention by the Federal Reserve Board did prevent a systemic failure of the banking and financial system in the U.S. The contractionary impact of the Asian crisis was therefore more subdued.

The internet bubble (also known as dot-com bubble) was sector-specific in nature. It originated from the accelerated growth in internet sectors, which led to the rapid run-up in market valuations on the internet related industries. When the bubble burst in 2000, it was followed by an equally rapid collapse of the markets and led to bankruptcy of many internet firms and huge losses in stock markets. The bubble had an important impact on the wealth and the spending habits of consumers, especially those in the developed countries. People spent more because they felt richer with their overvalued assets; but when their wealth was suddenly reduced once the bubble burst, they scaled back on discretionary spending. Changes in discretionary spending are a result of the so-called "wealth effect”, which turns out to have important implications for the growth of international trade and the global economy. For many export-oriented countries, this surge in discretionary spending in developed countries, especially in high-tech products, was for a long time a major source of global demand for their exports. ${ }^{7}$ After the internet bubble bursting and the 9/11 attacks, countries with a heavy reliance on the exports of high-tech products such as Japan, Singapore,

\footnotetext{
${ }^{7}$ The export structure in Asia had changed dramatically, from resource-intensive and labor-intensive industries to more skilled and more capital-intensive industries. This together with strong intraregional links exposed Asian economies to greater risks of external shocks.
} 
South Korea and Taiwan saw the global demand for Information, Communication and Technology (ICT) products slowing in a weak economic outlook. Similarly, the exports of other Asian countries such as Malaysia and the Philippines, which are part of the integrated ICT supply chain in the region, were also negatively affected. China, meanwhile, still managed to experience positive growth in exports as the volume of Chinese high-tech exports constituted only a small part of its external trade at that time and hence the impacts were limited.

Unlike the export contractions seen in 1997 and 2001, which were limited mainly to certain region (Asia) or certain industries (high-tech), a shrunken export demand in 2008 was truly global as a result of a great economic recession unlike any seen since the early 1930s. In varying degrees, this great economic recession affected virtually every industry and business sector. The reason why the recent economic downturn has had far-reaching consequences lies in the rapid proliferation of speculative financial innovations fuelled by a torrent of cross-board capital flows that further quickened the speed of contagion worldwide (Hu, 2009). As a consequence, the economic impacts of a lowered level of world income were felt around the globe, and a collapse in export demand across the board quickly followed. This included a plunge in global demand for Chinese output.

In general, exports contracted largely due to the declines in worldwide demand, an important growth predictor that has been identified in the trade literature to be one of the most significant fundamental factors underlying exports. However, as shown in Tables 1 and 2, world trade fell more rapidly than output in varying degrees across nations when a crisis occurred. In the 2008 crisis, for example, world GDP fell -1.86\% from the previous year but exports fell more rapidly, with $-18.52 \%$ and $-22.18 \%$ for Asia5 and OECD countries, respectively. Similarly, large declines in exports also took 
place in the two previous crises. With these observations and the distinct V-shaped patterns in exports as shown in Figure 1 and 2, we suspect that exports may have fallen much more rapidly to an extent far exceeding what can be entirely attributed to the changes in fundamental factors. Thus, we have the following hypothesis:

Hypothesis 1: During crisis, exports overshoot the deviation bands allowed by the long run equilibrium relationship governed by the fundamental factors.

In the three episodes of fast falling export demand, the impacts in the 2008 crisis were the largest, for the contagion was more severe and truly global, leading to a much weaker global demand (Sun, 2009). The drying up of trade credit and traders' overreaction to a possible collapse in demand made the situation even more serious in the 2008 crisis (Athukorala and Kohpaiboon, 2009). However, a variety of economic stimulus packages were put in place in a timely manner to lessen the negative impact thanks to the quick and coordinated responses from the world's governments in containing the spread and further worsening of the crisis. It is therefore reasonable to believe that exports would rebound more quickly in the 2008 crisis than in the other crises. The export impacts were much greater in the 2001 crisis than in the 1997 crisis. The fact that both the extent of the impacts and the speed of rebound increased over time can also be observed in Figure 1 and 2, where the V-shaped pattern of the export contractions became much narrower in the more recent crisis. Thus, we have:

Hypothesis 2: Although the degree of export contractions was much sharper in the more recent crisis, exports also bottomed out much quicker.

Moreover, because industries were affected to varying degrees by the three crises and their recovery dynamics were also different, we examine how exports were impacted at the industry level by classifying a country’s manufacturing industries into 
two groups, Group A and Group B, based on their industry characteristics. Group A consists of industries whose production activities tend to be capital- or technology-intensive in nature. Specifically, Group A includes electronics, machinery, electrical equipment, ICT (information, communications and technology), transportation, and precision instruments. The demand for Group A is highly income elastic, and consumer spending on such products tends to follow the ebb and flow of the economy. Spending decreases during economic downturns and increases when the economy expands. Notice that developed countries are the major buyers of Group A. On the other hand, Group B, consisting of all remaining industries, ${ }^{8}$ tends to be labor-intensive and of necessity in nature. While developing countries are the major consumers of Group B, developed countries may reduce their consumption as a result of an increase in income. With this in mind, we postulate:

Hypothesis 3: Group A's capital- or technological-intensive exports tend to increase with the levels of OECD income, while Group B's labor-intensive exports tend to increase with the levels of Non-OECD income.

\section{Empirical Model}

To examine how exports adjust to shocks, we need to explicitly model their adjustment by introducing an a-priori long-run equilibrium relationship, with the hypothesis that there exists an error correction mechanism that makes the short-run deviations to converge on a long-run trend. Therefore, modeling a long-run export performance in the context of adjustment to external shocks is inherently dynamic.

Assume export performance $E_{i t}$ is affected by a set of fundamental factors $Z_{i t}$

\footnotetext{
8 They are textiles, apparel, plywood, paper, furniture, rubbers and plastics, metal products, nonmetal products, basic metal, printing, chemical materials, chemical products, and petroleum.
} 
and some global shocks (denoted as Crisis). Let the short-run relationship among $E X_{i t}, Z_{i t}$ and Crisis follow an autoregressive-distributed lag model:

$$
E X_{i t}=\alpha_{0}+\alpha_{1} Z_{i, t}+\alpha_{2} Z_{i t-1}+\alpha_{3} E X_{i t-1}+\alpha_{4} \operatorname{Crisis}_{t}+\varepsilon_{i, t}
$$

where $E X_{i t}(i=1, \ldots N, t=1, \ldots, T)$ is country $i$ 's exports in log form at time t. Crisis, which includes 1997Crisis, 2001Crisis, and 2008Crisis, is a period dummy used to capture the common shocks from the 1997, 2001 and 2008 crises. $\varepsilon_{i t}\left(=v_{i}+u_{i t}\right)$ includes country-specific variables $v_{i}$ and the stochastic error term $u_{i t}$, where the former is to reflect country-specific effect stemming from cross-country differences in endowment, technology, and so on.

Two problems may arise when using panel data regression techniques to determine the dynamic relationships between of $E X_{i t}$ and $Z_{i t}$ as indicated in Equation (1). ${ }^{9}$ First, we run into the endogeneity problem caused by the difficulty of identifying the unobserved country-specific effects such as technological progress in a dynamic setting, in which case the right-hand-side variables are not orthogonal to each other. Second, the problem of persistence occurs because $E X_{i t}$ and $Z_{i t}$ tend to be highly persistent over time with their respective lagged values and are often jointly determined, which is often the case for economic research using time series of macroeconomic variables. ${ }^{10}$

An error correction model is therefore adopted, which can be used to solve for these two problems. Most importantly, it has the advantage of allowing us to examine the short-run and long-run dynamics of the relationship between $E X_{i t}$ and $Z_{i t}$, and

\footnotetext{
${ }^{9}$ SeeYasar et al. (2006).

${ }^{10}$ The Durbin-Watson statistic, which is 0.35 for regression (1), suggests the existence of autocorrelation.
} 
this feature becomes very useful, especially in the context of examining how exports behave when an external shock is present.

$$
\Delta E X_{i t}=\alpha_{1} \Delta Z_{i t}+\eta E R R O R_{i t-1}+\alpha_{4} \text { Crisis }_{t}+\varepsilon_{i t}
$$

where $\Delta$ indicates first difference, $E R R O R_{i t-1}\left(=E X_{i t-1}-\phi_{0}-\phi_{1} Z_{i t-1}\right)$ is the error correction term, $\phi_{0}=-\alpha_{0} /\left(1-\alpha_{3}\right), \phi_{1}=-\left(\alpha_{1}+\alpha_{2}\right) /\left(1-\alpha_{3}\right)$, and $\eta=-\left(1-\alpha_{3}\right)$. In equation (2), $\Delta Z_{i t}$ captures the short-run effects while $E R R O R_{i t-1}$ describes the long-run dynamics. Exports could deviate from the long-run equilibrium relationship owing to random shocks in the short run, but eventually converge to the equilibrium when shocks are absent. The error correction coefficient $\eta$, which is negative for such a convergence to occur, therefore measures the speed of adjustment toward the long-run equilibrium.

Crisis is used to see whether there exists excessive adjustment in exports that cannot be explained by the effects of short-run and long-run dynamics. If the coefficient of Crisis is significantly different from zero, then there exists the so-called “export overshooting” phenomenon. We indicate the beginning of a crisis using the timing of export growth once it turns negative. That is, a crisis begins once negative export growth is present in any of the countries in our sample. For example in the 2001 crisis, Taiwan was the country whose exports fell earlier than those of the others, so the month when Taiwan's export growth first turned negative is defined as the starting month of the downturn, which was January 2001. The subsequent months of the crisis period are defined as follows: Crisis2001= 2 if February 2001, Crisis2001= 3 if March 2001...., and Crisis2001=18 if June 2002, when the U.S. was the last country to resume positive growth in exports. By adding Crisis and its square term (Crisis_SQ), we are able to figure out, on average, how many months it took to reach 
the trough of the contraction in growth. Crisis1997 and Crisis2008 can be similarly defined (see Table 3). ${ }^{11}$

The set of fundamental factors $Z_{i t}$ affecting a country's export performance includes world demand, effective exchange rate, volatility of exchange rate and FDI flows. Here, world GDP is used to measure world demand. As a larger world GDP is expected to boost a country's exports, we expect a positive relationship between the two variables. The effective exchange rates, which are trade-weight-based measures with weights being time-varying, are obtained from the Bank for International Settlements. Since the appreciation of a country's currency lowers the competitiveness of its exports, export volume falls as a result. However, currency appreciation also raises export prices. The effect of an increase in EER on export values therefore depends on the price elasticity. The effect is positive if products are highly elastic (e.g., ICT); but it is negative if products are less elastic (e.g., necessities).

The volatility of effective exchange rates $\rho$ is used to capture the impact of exchange-rate uncertainty, where $\rho$ is constructed as the moving average of the deviation of EER from its mean over the last 12 months:

$$
\rho=\left[\frac{1}{12} \sum_{j=1}^{12}\left(E E R_{t-j}-\overline{E E R_{t}}\right)^{2}\right]^{0.5}
$$

Theoretically, the impact of exchange rate volatility on exports may be positive or negative depending on the assumption made with respect to risk preference (De Grauwe, 1988). For risk-averse exporters, higher exchange rate volatility increases the extent of uncertainty and thus negatively impacts exports. On the contrary, for those

${ }^{11}$ Crisis1997= 1 if November 1997 when Japan was the first country among Asia whose export growth turned negative, ..., and Crisis1997=18 if April 1999, when Korea was the last country to resume positive growth in exports. Similarly, Crisis2008 $=1$ if September 2008 when Taiwan was the first country among Asia whose export growth turned negative, ..., and Crisis2008=20 if April 2010, when Korea was the last country to resume positive growth in exports 
who are risk-loving, higher exchange rate volatility is often associated with higher exports. Moreover, when exports are considered as an option by exporters, exports may increase with exchange rate volatility (Boug and Fagereng, 2010). Since exporters may be able to reduce or hedge against exchange rate uncertainty, the linkage between exchange rate volatility and exports may be insignificant (Solakoglu, 2008).

FDI is another factor affecting exports. Whether or not FDI contributes to the export performance depends on the motive of FDI. Tariff-jumping FDI, which aims at host market, may not help the host country to expand exports. Export-oriented FDI, on the other hand, uses a host country as an export platform and may contribute to the exports of host countries. Since aggregate FDI is used, of which motivations cannot be identified, we have no prior expectation of the sign of FDI.

We first run the long-run regression $E X_{i t}=\phi_{0}+\phi_{1} Z_{i t}+\varepsilon_{i t}$ to derive the error correction term $\left(E R R O R_{i t-1}=E X_{i t-1}-\left(\widehat{\phi}_{0}+\widehat{\phi}_{1} Z_{i t-1}\right)\right)$, which is then used to run Equation (2). The definition and descriptive statistics of the variables are summarized in Table 3, while the Error Correction Model results for Regression (2) are reported in Table 4.

\section{Regression Results}

Two specifications are reported in Table 4 for the full sample. Specification (1) uses world GDP as a measure of world demand, while Specification (2) uses OECD and non-OECD GDP, instead. It shows that while non-OECD GDP had positive effects on world exports as expected, OECD GDP had negative impacts on exports. This suggests that the demand from the non-OECD countries was the driving force behind the growth of world exports for the last fifteen years or so. And since OECD 
and non-OECD GDP have opposite effects on world exports, their sum (i.e., world GDP) may not be a good measure of demand for exports; we therefore discuss the regression results with OECD and non-OECD GDP as demand-side variables in the following.

Specification (2) in Table 4 shows that the volatility of effective exchange rate, which has mixed results in the literature (De Grauwe, 1988), is shown to have negative impacts on exports. The real effective exchange rate (EER) is positive but FDI inflows are insignificant in the full sample. The error correction term (ERROR) is negative and statistically significant, suggesting that there exists a long-run relationship between export performance $(E X)$ and fundamental factors $(Z)$, and that the gap between $E X$ and those explained by $Z$ can be closed through the error correction mechanism. The speed of the short-run correction $(\eta)$ is -0.14 , indicating, on average, about $14 \%$ of the gap is corrected in each month.

The signs of 2001Crisis and 2008Crisis are negative but the signs of their square terms are positive, indicating that there exist remarkable effects of the two crises on exports, manifested in striking V-shaped growth patterns. This supports Hypothesis 1 that exports had contracted excessively during the economic downturns such that shrinkage in world demand and changes in other fundamental factors were insufficient to explain the fluctuations in exports. For the 1997 crisis, however, the V-shaped growth patterns did not occur in the full sample. In fact, the export growth rate even increased but at a decreasing rate (as shown by the positive sign of Crisis1997 and the negative sign of Crisis1997_SQ), indicating an inversed V-shaped pattern in export growth (Specification (2) in Table 4). This confirms the observation that the Asian financial crisis did not spread across wide regions of the world and that world exports, on average, were still slowly growing in the midst of a crisis. 
Moreover, Table 4 shows that the V-shaped pattern is significantly deeper and narrower in the 2008 crisis than in the 2001 crisis. That is to say, not only did exports contract more rapidly, they also rebounded more quickly in the recent crisis. Using the coefficients for the crisis variable and its square term, we can calculate the number of months for the economies to reach the trough of the economic recession. It shows that the 2008 financial crisis bottomed out more quickly than the previous crisis in 2001 (i.e. 8.24 vs. 9.96 months) for Specification (2). This supports Hypothesis 2 as discussed in Section 2.

The unusual reversed V-shaped export growth pattern, which occurred in the 1997 crisis for the full sample, may no longer hold when a smaller group of sample is used. Four subgroups are considered here, i.e., OECD_DC, OECD_LDC, Asia_DC, and Asia_LDC, depending upon whether a country belongs to OECD or Asia, and is advanced economy or not as defined by IMF. ${ }^{12}$ The results show that while OECD subgroups displayed reversed V-shaped pattern in export growth (Table 5), Asian countries did experience export overshooting in the 1997 financial crisis (Table 6). The results that the exports of Asian countries had fallen excessively but those of OECD countries had increased excessively (i.e., the phenomenon of reversed overshooting) may be explained by the facts that the 1997 Asian financial crisis was a regional shock in nature. The large GDP contraction in Asia and the increasing importance of intra-regional trade within Asia significantly contributed to the export overshooting. For the 2001 and 2008 crises, export overshooting, however, occurred for both OECD and Asian subgroups and was increasing over time, as seen by the declining magnitude of the negative estimators associated with the crisis variables. Exports also bounced back more quickly over time. For the OECD countries, the

${ }^{12}$ See World Economic Outlook. Database: WEO Groups and Aggregates Information, October 2009. 
number of months it took for the export contraction to bottom out was improving, i.e., 10.74 and 8.37 months for the 2001 and 2008 crises, respectively; for the Asian countries the corresponding figures are 11.71, 9.07, and 7.69 months for the 1997, 2001, and 2008 crises, respectively (Table 8). These figures reveal an interesting conclusion that the Asian economies bounced back more quickly from the crises than the OECD countries, a phenomena that deserves further explanation.

When the Asian sample is further divided into two industry groups, Group A and Group B, according to whether the industry is high-tech, more insights emerge (Table 7). The export overshooting seen for Asian countries in the 1997 crisis was mainly due to the excessive fall in exports for Group B rather than for Group A; indeed, the exports of Group A did not even fall when controlling for other variables, as indicated by the positive (but not significant) sign of Crisis1997. The result is consistent with the fact that developed countries, which are the major source of demand for the high-tech products, were less affected by the Asian crisis.

In addition to export overshooting, Group A and Group B also differ in income elasticity of exports. Most of income elasticity was positive, consistent with the normality assumption of goods. But, exports of Group B, which tend to be of necessity in nature, were negatively (although insignificantly) affected by OECD GDP, implying that Group B may not be normal goods. Moreover, Group A is more sensitive to the OECD's GDP while Group B is more responsive to the non-OECD's GDP, conforming to Hypothesis 3 discussed in Section 2. The effect of real effective exchange rate (EER) is positive for Group A but negative for Group B. This suggests that Group B may be more sensitive to price competition than Group A, and the depreciation of EER is effective in expanding the exports of Group B.

The adjustment speed $\eta$ associated with the error correction term is also 
different across different industry groups; it is much faster for Group B (-0.24) than that for Group A (-0.10). This implies that Group B is more stable than Group A in its long-run-export trend, which is consistent with the fact that Group A is highly income elastic and tend to have large oscillations around the trend.

While the exports were hit harder for Group A (mainly the high-tech products) than for Group B in the 2001 crisis, the opposite was true in the 2008 crisis. This may be due to the fact that compared to the internet bubble around 2001 where the high-tech industries were the target of the crisis, the global financial crisis in 2008 was more widespread such that it affected almost every industry and every country in the world. But in both crises, Group A bottomed out more quickly than Group B (Table 8).

\section{Some Possible Explanations}

The discussions in Section 4 suggest that export overshooting did occur in the 2001 and 2008 crises. This holds for the full sample, advanced countries, Asian economies, as well as emerging markets, and for the high-tech (Group A) and low-tech (Group B) products. Given the fact that the export share of full sample studied here accounts for about $80 \%$ of world exports in 2008 , the above results suggest that export overshooting was a world-wide phenomenon when the crises occurred. However, the Asian financial crisis in 1997 was a regional event and had rather limited impact outside Asia, export overshooting therefore occurred only within the Asian region.

Why did the export contraction significantly overshoot its long-run trend when an economic crisis occurred in 2001 and 2008? Why did exports fall much deeper and yet bounce back much more quickly in the 2008 crisis than in the 2001 crisis? All 
these questions may be partially explained by the so-called Forrester effect on demand variability, a phenomenon well known in the optimization of supply chain and inventory control systems.

The Forrester effect suggests that demand variability increases as one moves up a supply chain. It is a feedback mechanism set forth by external shocks to the supply chain where small fluctuations in demand at the retailer end are dramatically amplified as they proceed up the chain. Such an effect may be caused by the demand forecast updating that reflects not only the need to replenish the stocks to meet the requirements for future demands but also the need for safety stocks which are considered necessary because of the large demand uncertainty and fluctuation (Lee et al., 1997). As a result, the readjustment of demand forecast by the upstream manager is often greater than the change of demand in the downstream. Similarly, periodic ordering (which makes suppliers face a highly erratic stream of orders), special sales promotion (which triggers irregular buying pattern of customers) and rationing (which occurs when demands exceed supply) may all distort demand information (Lee et al., 1997). Inaccuracies and volatility of orders from the retailer to the primary suppliers therefore cause relatively greater readjustments at each point of the chain. Apparently, the amount of safety stock contributes significantly to the Forrester effect. As in the visual metaphor of cracking a bullwhip, demand in the chain fluctuates in a continuous and long lasting oscillatory movement upstream; therefore, it is also labeled the bullwhip effect.

To make things clear, consider a $10 \%$ drop in retail sales. In order to deplete the surplus stocks and reduce inventory, given that there is now a weaker sales outlook, orders placed by retailers to wholesalers one step upstream in the chain will thus decrease by more than $10 \%$, say $15 \%$. The decrease in demand amplifies and 
propagates through the chain as upstream firms react in much the same way as downstream firms do, trying to adjust their stock level and empty the pipeline. Hence the longer the supply chain is, the more pronounced the upstream demand amplification (or the larger the oscillatory movement) will become. This will result in an even greater decrease, say $20 \%$, in purchase orders to the suppliers further upstream in our example.

The "export overshooting" phenomenon as seen in OECD and Asian economies in the 2001 and 2008 crises, in essence, captures the bullwhip effect. While the real world GDP fell only mildly in 2001 and 2009, exporting countries, constituting the upper stream end of the global supply chain, had experienced a much greater fall in exports which cannot be fully explained by the changes in consumer demand as well as other fundamental factors such as exchange rates, the volatility of exchange rates and FDI (Table 4 to Table 7). The adjustment of inventory and the overcorrection of the demand forecast by every entity in the global supply chain was indeed the force at work that caused manufacturing orders (exports) to fall more than the decline in demand at the retailer end of the chain. Table 9 provides some evidence from Taiwan to support this argument. It summarizes the growth rates of export orders and inventory for the upstream (electronic parts and components) and the downstream (computers, electronic and optical products) in Taiwan. It shows that when the crisis occurred in the late 2008 and exerted its negative impact throughout 2009, the downstream industry reacted to demand contraction by depleting its inventory first, as indicated by the quickly fall in the growth rate of its inventory in the late 2008. Thus, while the orders placed by foreign buyers on both the upstream and downstream industries were contracted, the orders on the upstream fell more than those on the 
downstream. ${ }^{13}$ Similar results can also be observed during 2001-2002 when the internet bubble took effect.

When the economy recovered, the bullwhip effect also worked in much the same way but in the opposite direction; exports bounced back by a much larger extent than the actual increase in demand as every entity of the supply chain increased its safety stocks to meet unexpected increase in future demand. This can also be observed from Table 9: the extent of rebound in export orders received by the Taiwanese firm was larger for the upstream than for the downstream in 2003-2004 and in the late 2009 when economy showed signs of recovery after 2001 and 2008 crises.

The reason why the extent of export overshooting increased over time as shown in the previous section may be explained by an increasing specialization of production vertically over time. Generally, when production becomes more specialized vertically around the world, the length of a supply chain increases, and so does the extent of the bullwhip effect (or the extent of overshooting). As already discussed earlier, bullwhip effect causes modest changes at one end of the chain to be magnified with a fast-cascading impact when reaching the other end. This means literally that the longer the supply chain, the larger the demand swings for the upstream end of the chain. Therefore, as the degree of cross-border vertical specialization increases over time, the demand variability is also increased in an elongated chain, and thus enhancing the global supply system’s tendency to overcorrect. This helps explain why the overshooting phenomenon was more pronounced in the 2008 crisis than in the 2001 crisis. The findings from Vlasenko (2009) that firms' inventory levels were quickly deteriorating in the 2008 crisis at a faster speed than the average rate in the

\footnotetext{
${ }^{13}$ Note that due to the lack of foreign data, we assume the downstream industry in foreign country adjusts its inventory in much the same way as that in Taiwanese. This assumption is plausible as Taiwan is the major supplier of electronics and ICT products.
} 
previous recessions provide some evidence of an increasing overcorrection in the supply system. This in turn, we believe, had led to an increase in the extent of overshooting (bullwhip effect), supporting our argument that the recent financial crisis was worse than the previous crisis in terms of the rates of decline in world exports.

The above bullwhip effect can be used to explain why high-tech industries (Group A) bottomed out more quickly than low-tech industries (Group B). Since high-tech industries tend to be more sophisticated and have a supply chain longer than low-tech industries, the economic crisis will have a bigger export impact on high-tech than on low-tech in terms of the speed of fall and the pace of rebound according to the above discussion. This also helps explain why Asian exports bounced back more quickly than the crisis than OECD countries as shown by the regressions in Section 4, as Asian countries are the major high-tech exporters. ${ }^{14}$

\section{Concluding Remark}

This paper provides some evidence of the "export overshooting” phenomenon, i.e. the unusually large deviation of exports from their long-run level, which can not be fully explained by the fundamental factors such as the changes in worldwide demand, effective exchange rates, the volatility of exchange rates and FDI. We show that export overshooting that had occurred in the 2001 and 2008 economic crises was a world-wide phenomenon. In fact, it prevailed in all of the 37 countries in our sample that represent different income groups: developed countries, Asian NICs, and emerging market countries. But for the 1997 crisis which was a regional financial crisis in nature, export overshooting only occurred within the Asian region and did not spread beyond Asia.

\footnotetext{
${ }^{14}$ While the high-tech export share for EU and US were 49\% and 55\% during 2000-2007, respectively, the corresponding figure for the Asian economies studied in this paper was 58\%.
} 
We argue that the bullwhip effect was indeed a driving force behind the "export overshooting” phenomenon. Because of the adjustment in inventory and overcorrection in demand forecast by every entity of the supply chain when facing a shock (economic crisis), exporting countries, which were at the upstream end of the supply chain, faced a much greater demand oscillation than the demand at the retailer end. As a result, exports fell more than demand at the retail end; but when the economy recovered exports also bounced back by a larger extent than the change in final demand. The export overshooting phenomenon discussed in this paper may therefore be regarded as a magnified version of the bullwhip effect in world exports, which was triggered by the large negative aggregate demand shocks resulting from the global economic crises.

The extent of overshooting, however, changes overtime and differs across industries. As production becomes more vertically specialized across countries over time (Hummels et al., 1998), the supply chain becomes longer accordingly. A longer supply chain implies larger demand variability and bigger export fluctuations when economic crisis occurs. This helps explain why the extent of export overshooting was greater and the rebound of exports was also quicker in the 2008 crisis as compared to the 2001 crisis. Moreover, high-tech industries tend to have longer supply chain and hence face larger demand variability. The speed of fall and the pace of rebound in exports were therefore faster in the high-tech industries than in the low-tech industries. As Asian countries were the major high-tech exporters, this also helps explain why Asian exports bounced back more quickly than OECD exports. 


\section{References}

Authukorala, P.C. and Kohpaiboon, A. (2009) Intra-Regional Trade in East Asia: The Decoupling Fallacy, Crisis, and Policy Challenges. ADBI Working Paper Series No. 177.

Berkmen P., Gelos G., Rennhack, R., and Walsh J.P. (2009) The Global Financial Crisis: Explaining Cross-Country Differences in the Output Impact, IMF Working Paper WP/09/280.

Bhaskaran, M. and Ghosh, R. (2010) Global Economic and Financial Crisis Impact on Developing Asia and Immediate Policy Implications. ADB Regional Forum.

Boug, P. and Fagereng, A. (2010) Exchange Rate Volatility and Export Performance: A Cointegrated VAR Approach. Applied Economics, 42(7), 851-864.

Das, D. K., 1999, Implications of the Financial Crisis for Asian Exports, EDRC Briefing Notes No. 8, Asian Development Bank.

De Grauwe, P. (1988) Exchange Rate Volatility and the Slowdown in Growth of International Trade. IMF Staff Papers No. 35, 63-84.

Haraguchi, N. (2010) Impacts of the Global Economic Crisis on the Thai Automotive Industry: From the Perspective of the interplay between Shocks and the Industrial Structure, UNIDO Working Paper 07/2009.

Hu, S.C. (2011), 'Global Financial Crisis: Lessons for Taiwan,’ in Daigee Shaw and Bih Jane Liu (eds.) The Impact of the Economic Crisis on East Asia, Chapter 1. Edward Elgar Publishing Ltd., London.

Hummels, D., Rapoport, D., and Yi, K-M, 1998, Vertical Specialization and the Changing Nature of World Trade, Economic Policy Review, 79-99.

Goldstein, M. (1998) The Asian Financial Crisis: Causes, Cures, and Systemic Implications, Policy Analysis in International Economics 55, Institute for International Economics.

Grobar, L.M. (1993) The Effect of Real Exchange Rate Uncertainty on LDC Manufactured Exports. Journal of Development Economics, 41, 367-376.

Kawai, M. and Takagi S. 2009, Why Was Japan Hit so Hard by the Financial Crisis? Paper presented at the Samuel Hsieh 
Kutan, A.M. and Goran, V. (2007) Foreign Direct Investment and Export Performance: Empirical Evidence, Comparative Economic Studies.

Kuroiwa, I. and H. Kuwamori, 2010, Shock Transmission Mechanism of the Economic risis in East Asia: An Application of International Input-Output Analysis, IDE Discussion Paper No. 220

Klau, M. and Fung, S.S. (2006) The New BIS Effective Exchange Rate Indices. BIS Quarterly Review, 51-65.

Lee, H.L., Padmanabhan V. and Whang S. (1997) The Bullwhip Effects in Supply Chains. Sloan Management Review, 93-102.

Lin, J.Y. (2008) The Impact of Financial Crisis on Developing Countries. World Bank.

Liu, B.J., Lu, A. and Tung, A.C. (2007) Export Outsourcing: Cost Disadvantage and Reputation Advantage. In Yotopoulos, P.A.and Romano, D. (eds.), The Asymmetries of Globalization, Routledge, London, 108-125.

Liu, B.J. and Lu, A. (2007) The Economic Impact of Export Outsourcing and Policy Implication. Research Report, Council for Economic Planning and Development, Executive Yuan, R.O.C. (Taiwan).

Liu, B.J. (2010) The Impact of Global Financial Crisis on Taiwan's Export Outsourcing, Exports, and Employments. Research Report, Council for Economic Planning and Development, Executive Yuan, R.O.C. (Taiwan).

Sapir, A. and Sekkat, Kh. (1995) Exchange Rate Regimes and Trade Prices: Does the EMS matter? Journal of International Economics, 30, 75-95.

Zhang, K.H. and Song, S. (2000) Promoting Exports: The Role of Inward FDI in China. China Economic Review, 11, 385-396.

Solakoglu, M.N., Solakoglu, E.G. and Demirag, T. (2008) Exchange Rate Volatility and Exports: A Firm-level Analysis. Applied Economics, 40, 921-929.

Sun, M. (2009) China: Unscathed through the Global Financial Tsunami. China \& World Economy, 17(6), 24-42.

Valliere, D. and Peterson R. (2004) Inflating the Bubble: Examining Dot-Com Investor Behavior. Venture Capital,6(1), 1-22.

Vlasenko, P. (2009) Have Firms Become Better Equipped to Handle Recession? 
American Institute for Economic Research. http://www.aier.org/research/briefs /1366-have-firms-become-better-equipped-to-handle-recessions.

Yang, T. and J.J. Lim (2004), Crisis, Contagion, and East Asian Stock Markets, Review of Pacific Basin Financial Markets and Policies 7(1), 119-151.

Yasar, M., C. Nelson and R. Rejesus (2006), The Dynamics of Exports and Productivity at the Plant level: A Panel Data Error Correction Model (ECM) Approach. In: B. Baltagi, Editor, Panel Data Econometrics: Theoretical Contributions and Empirical Applications, Elsevier, Amsterdam (2006). 
Table 1 Growth Rate of GDP for OECD, Non-OECD and the World, 1995-2009

\begin{tabular}{|c|c|c|c|c|c|c|}
\hline Year & World & OECD & $\begin{array}{c}\text { Non-OEC } \\
\text { D }\end{array}$ & $\begin{array}{l}\text { Asian } \\
\text { NICs }\end{array}$ & ASEAN & $\begin{array}{c}\text { Latin } \\
\text { America }\end{array}$ \\
\hline 1995 & 2.81 & 2.47 & 4.40 & 8.11 & 8.27 & 3.21 \\
\hline 1996 & 3.21 & 2.83 & 4.85 & 7.31 & 8.26 & 2.94 \\
\hline 1997 & 3.61 & 3.34 & 4.66 & 6.28 & 7.38 & 4.72 \\
\hline 1998 & 2.35 & 2.46 & 1.93 & 5.24 & 4.21 & 1.23 \\
\hline 1999 & 3.25 & 3.27 & 3.20 & -3.33 & -6.67 & -1.21 \\
\hline 2000 & 4.28 & 4.03 & 5.39 & 6.91 & 4.20 & 2.76 \\
\hline 2001 & 1.65 & 1.23 & 3.40 & 7.81 & 6.62 & 0.41 \\
\hline 2002 & 2.02 & 1.55 & 4.02 & 1.28 & 1.93 & -0.63 \\
\hline 2003 & 2.67 & 1.89 & 6.00 & 5.57 & 4.97 & 1.97 \\
\hline 2004 & 3.92 & 3.03 & 7.59 & 3.13 & 5.53 & 6.90 \\
\hline 2005 & 3.52 & 2.58 & 7.08 & 5.87 & 6.53 & 5.09 \\
\hline 2006 & 4.09 & 2.98 & 7.85 & 4.78 & 5.81 & 5.56 \\
\hline 2007 & 4.03 & 2.67 & 8.18 & 5.71 & 6.11 & 6.56 \\
\hline 2008 & 1.95 & 0.44 & 6.09 & 5.68 & 6.47 & 5.20 \\
\hline 2009 & -1.86 & -3.41 & 2.01 & 1.94 & 4.32 & -0.33 \\
\hline
\end{tabular}

Source: Global Insight. 
Table 2: $1995-2009$ Growth Rates of Exports by Country, \%

\begin{tabular}{|c|c|c|c|c|c|c|}
\hline Year & Asia5* & Taiwan & Japan & Korea & China & Indonesia \\
\hline 1995 & 17.59 & 20.00 & 11.5 & 30.53 & 25.46 & 13.49 \\
\hline 1996 & -1.93 & 3.57 & -7.13 & 4.03 & 1.52 & 9.83 \\
\hline 1997 & 6.64 & 4.40 & 2.59 & 4.74 & 20.98 & 7.28 \\
\hline 1998 & -5.53 & -8.72 & -7.7 & -2.65 & 0.55 & -8.6 \\
\hline 1999 & 7.49 & 10.07 & 7.82 & 8.14 & 6.22 & -0.37 \\
\hline 2000 & 19.64 & 21.67 & 13.98 & 20.41 & 27.7 & 27.66 \\
\hline 2001 & -10.06 & -17.06 & -15.45 & -12.48 & 6.89 & -9.34 \\
\hline 2002 & 9.38 & 6.65 & 3.16 & 7.54 & 22.24 & 1.49 \\
\hline 2003 & 19.83 & 10.34 & 13.08 & 19.15 & 34.65 & 6.82 \\
\hline 2004 & 25.31 & 21.03 & 19.56 & 31.03 & 35.39 & 17.24 \\
\hline 2005 & 14.68 & 8.38 & 5.52 & 12.01 & 28.41 & 19.66 \\
\hline 2006 & 19.18 & 12.72 & 8.8 & 14.38 & 27.15 & 17.67 \\
\hline 2007 & 18.49 & 10.19 & 10.44 & 14.21 & 25.67 & 13.2 \\
\hline 2008 & 13.49 & 3.63 & 8.22 & 13.65 & 17.3 & 20.09 \\
\hline 2009 & -18.52 & -20.32 & -24.77 & -14.5 & -15.87 & -14.97 \\
\hline Year & $\mathrm{OECD}^{* *}$ & US & UK & France & Germany & Italy \\
\hline 1995 & 19.89 & 14.07 & 17.96 & 22.19 & 22.20 & 13.35 \\
\hline 1996 & 6.25 & 6.9 & 8.32 & 1.12 & 0.35 & 15.92 \\
\hline 1997 & 2.75 & 10.25 & 7.07 & -2.18 & -2.14 & -2.97 \\
\hline 1998 & 1.99 & -1.02 & -3.10 & 5.98 & 5.50 & 0.64 \\
\hline 1999 & 1.96 & 2 & -0.95 & 1.61 & -0.40 & -3.71 \\
\hline 2000 & 6.66 & 12.38 & 5.51 & 1.15 & 2.13 & 3.65 \\
\hline 2001 & -1.15 & -6.75 & -4.28 & -1.11 & 3.87 & 1.56 \\
\hline 2002 & 3.41 & -4.93 & 2.54 & 2.44 & 7.74 & 3.69 \\
\hline 2003 & 14.40 & 2.93 & 9.59 & 18.39 & 22.11 & 18.27 \\
\hline 2004 & 18.08 & 13.19 & 13.39 & 14.49 & 20.04 & 16.53 \\
\hline 2005 & 8.25 & 10.79 & 10.02 & 2.73 & 7.09 & 6.49 \\
\hline 2006 & 14.95 & 14.36 & 16.98 & 7.65 & 14.66 & 12.71 \\
\hline 2007 & 14.55 & 11.27 & -2.04 & 11.11 & 19.12 & 19.04 \\
\hline 2008 & 11.68 & 14.63 & 4.41 & 11.48 & 9.56 & 8.36 \\
\hline 2009 & -22.18 & -18.12 & -23.65 & -21.28 & -22.51 & -25.93 \\
\hline
\end{tabular}


Table 3: Variable Statistics and Definition-Full Sample

\begin{tabular}{|c|c|c|c|}
\hline Variables & Definition & Mean & $\begin{array}{c}\text { Standard } \\
\text { Deviation }\end{array}$ \\
\hline EX & $\begin{array}{l}\text { Monthly exports, in log; data sources: } \\
\text { SourceOECD and World Atlas. }\end{array}$ & 20.41 & 5.23 \\
\hline EX_GroupA & $\begin{array}{l}\text { Monthly exports for electronics, machinery, } \\
\text { electrical equipment, transportation, and } \\
\text { precision instruments; in log }\end{array}$ & 9.31 & 1.19 \\
\hline EX_GroupB & $\begin{array}{l}\text { Monthly exports for textiles, apparel, plywood, } \\
\text { paper, furniture, rubbers and plastics, metal } \\
\text { products, nonmetal products, basic metal, } \\
\text { printing, chemical materials, chemical products, } \\
\text { and petroleum; in log }\end{array}$ & 8.63 & 1.11 \\
\hline GDP_world & World GDP, quarterly, in log & 10.62 & 0.14 \\
\hline GDP_oecd & OECD GDP, quarterly, in log & 10.39 & 0.11 \\
\hline GDP_xoecd & Non-OECD GDP, quarterly, in log & 9.03 & 0.24 \\
\hline$\rho$ & Volatility of effective exchange rates, in log & 0.04 & 0.05 \\
\hline EER & Effective exchange rates, in log & 4.61 & 0.03 \\
\hline FDI & Inward direct investment ( $10^{3}$ billions) & 0.02 & 0.04 \\
\hline Crisis1997 & $\begin{array}{l}=1 \text {, if } 11 / 1997 ;=2 \text {, if } 12 / 1997 ;=2+i, \text { if the } i \text { th } \\
\text { month of } 1998 ;=14+j \text {, if the } j \text { th month of } 1999 \text {; } \\
j=1,2,3,4 ;=0 \text {, otherwise }\end{array}$ & 0.89 & 3.20 \\
\hline Crisis1997_SQ & Square term of Crisis1997 & 11.03 & 46.38 \\
\hline Crisis2001 & $\begin{array}{l}=i, \text { if the } i \text { th month of } 2001 ;=12+j \text {, if the } j \text { th } \\
\text { month of } 2002, j=1,2 \ldots, 6 ;=0 \text { otherwise }\end{array}$ & 0.91 & 3.22 \\
\hline Crisis2001_SQ & Square term of Crisis2001 & 11.17 & 46.54 \\
\hline Crisis2008 & $\begin{array}{l}=1 \text {, if } 9 / 2008 ;=2 \text {, if } 10 / 2008 ;=3 \text {, if } 11 / 2008 ;=4 \text {, } \\
\text { if } 12 / 2008 ;=4+i \text {, if the ith month of } 2009 ;=0 \text {, } \\
\text { otherwise }\end{array}$ & 1.00 & 3.47 \\
\hline Crisis2008_SQ & Square term of Crisis2008 & 13.04 & 53.07 \\
\hline OECD_DC & $\begin{array}{l}\text { =1, if Australia, Austria, Belgium, Canada, } \\
\text { Czech Republic, Denmark, Finland, France, } \\
\text { Germany, Greece, Iceland, Italy, Netherlands, } \\
\text { New Zealand, Norway, Portugal, Slovenia, } \\
\text { Spain, Sweden, Switzerland, United Kingdom, } \\
\text { United States }\end{array}$ & 0.62 & 0.49 \\
\hline OECD_LDC & $=1$, if Hungary, Mexico, Poland and Turkey & 0.11 & 0.31 \\
\hline Asia & $\begin{array}{l}=1 \text {, if China, India, Indonesia, Japan, Korea, } \\
\text { Malaysia, Philippine, Singapore, Taiwan and } \\
\text { Thailand }\end{array}$ & 0.28 & 0.45 \\
\hline
\end{tabular}


Table 4: Error Correction Model—Full Sample

\begin{tabular}{|c|c|c|c|c|}
\hline \multirow[t]{2}{*}{ Dependent variable: $\Delta \mathrm{EX}$} & \multicolumn{2}{|r|}{ (1) } & \multicolumn{2}{|r|}{$(2)$} \\
\hline & Coeff. & $\begin{array}{c}\text { Standard } \\
\text { Error }\end{array}$ & Coeff. & $\begin{array}{c}\text { Standard } \\
\text { Error }\end{array}$ \\
\hline ERROR Correction & -0.16 & $(0.01)^{* * *}$ & -0.14 & $(0.01)^{* * *}$ \\
\hline$\Delta$ GDP_World & -0.08 & $(0.22)$ & & \\
\hline$\Delta$ GDP_OECD & & & -2.28 & $(0.18)^{* * *}$ \\
\hline$\Delta$ GDP_XOECD & & & 2.52 & $(0.11)^{* * *}$ \\
\hline$\Delta$ EER_volatility & 0.03 & $(0.04)$ & -0.13 & $(0.03)^{* * *}$ \\
\hline$\Delta \mathrm{EER}$ & 0.18 & $(0.02)^{* * *}$ & 0.12 & $(0.02)^{* * *}$ \\
\hline$\Delta \mathrm{FDI}$ & 0.06 & $(0.06)$ & 0.07 & $(0.05)$ \\
\hline Crisis1997 & -0.02 & $(0.002)^{* * *}$ & 0.004 & $(0.002)^{* *}$ \\
\hline Crisis1997_SQ/100 & 0.05 & $(0.01)^{* * *}$ & -0.03 & $(0.01)^{* * *}$ \\
\hline Crisis2001 & -0.04 & $(0.002)^{* * *}$ & -0.03 & $(0.002)^{* * *}$ \\
\hline Crisis2001_SQ/100 & 0.20 & $(0.01)^{* * *}$ & 0.17 & $(0.01)^{* * *}$ \\
\hline Crisis2008 & -0.12 & $(0.004)^{* * *}$ & -0.12 & $(0.004)^{* * *}$ \\
\hline Crisis2008_SQ/100 & 0.71 & $(0.03)^{* * *}$ & 0.74 & $(0.02)^{* * *}$ \\
\hline constant & 0.13 & $(0.01)^{* * *}$ & 0.03 & $(0.01)$ \\
\hline R-Square: Within & & 6085 & & 0.6505 \\
\hline R-Square: Between & & 0241 & & 0.0248 \\
\hline R-Square: Overall & & 2091 & & 0.2566 \\
\hline No. of Observations & & 5660 & & 5660 \\
\hline No. of Countries & & 37 & & 37 \\
\hline
\end{tabular}

Note: Full sample includes 10 Asian countries and 27 OECD countries. 
Table 5: Error Correction Model for the OECD Sample

\begin{tabular}{|c|c|c|c|c|c|c|}
\hline \multirow[t]{2}{*}{$\begin{array}{l}\text { Dependent variable: } \\
\Delta \mathrm{EX}\end{array}$} & \multicolumn{2}{|c|}{$\begin{array}{l}\text { OECD } \\
(1)\end{array}$} & \multicolumn{2}{|c|}{$\begin{array}{c}\text { OECD_DC } \\
(2) \\
\end{array}$} & \multicolumn{2}{|c|}{$\begin{array}{c}\text { OECD_LDC } \\
(3)\end{array}$} \\
\hline & Coeff. & $\begin{array}{c}\text { Standard } \\
\text { Error }\end{array}$ & Coeff. & $\begin{array}{c}\text { Standard } \\
\text { Error }\end{array}$ & Coeff. & $\begin{array}{c}\text { Standard } \\
\text { Error }\end{array}$ \\
\hline ERROR Correction & -0.17 & $(0.01)^{* * *}$ & -0.18 & $(0.01)^{* * *}$ & -0.12 & $(0.02)^{* * *}$ \\
\hline$\triangle$ GDP_OECD & -3.03 & $(0.21)^{* * *}$ & -2.67 & $(0.23)^{* * *}$ & -3.11 & $(0.50)^{* * *}$ \\
\hline$\Delta$ GDP_XOECD & 2.69 & $(0.13)^{* * *}$ & 2.50 & $(0.14)^{* * *}$ & 3.60 & $(0.35)^{* * *}$ \\
\hline$\Delta$ EER_volatility & -0.05 & $(0.05)$ & 0.12 & $(0.08)$ & -0.21 & $(0.07)^{* * *}$ \\
\hline$\Delta \mathrm{EER}$ & 0.23 & $(0.02)^{* * *}$ & 0.34 & $(0.03)^{* * *}$ & 0.06 & $(0.03)^{* *}$ \\
\hline$\Delta \mathrm{FDI}$ & 0.01 & $(0.05)$ & 0.03 & $(0.05)$ & 0.07 & $(0.51)$ \\
\hline Crisis1997 & 0.01 & $(0.002)^{* * *}$ & 0.01 & $(0.002)^{* * *}$ & 0.02 & $(0.004)^{* * *}$ \\
\hline Crisis1997_SQ/100 & -0.04 & $(0.01)^{* * *}$ & -0.03 & $(0.01)^{* *}$ & -0.12 & $(0.03)^{* * *}$ \\
\hline Crisis2001 & -0.03 & $(0.002)^{* * *}$ & -0.03 & $(0.002)^{* * *}$ & -0.02 & $(0.005)^{* * *}$ \\
\hline Crisis2001_SQ/100 & 0.12 & $(0.01)^{* * *}$ & 0.12 & $(0.01)^{* * *}$ & 0.07 & $(0.03)^{* *}$ \\
\hline Crisis2008 & -0.13 & $(0.005)^{* * *}$ & -0.12 & $(0.01)^{* * *}$ & -0.13 & $(0.01)^{* * *}$ \\
\hline Crisis2008_SQ/100 & 0.77 & $(0.03)^{* * *}$ & 0.72 & $(0.03)^{* * *}$ & 0.81 & $(0.07)^{* * *}$ \\
\hline constant & 0.04 & $(0.01)^{* * *}$ & 0.02 & $(0.01)^{*}$ & -0.02 & $(0.03)$ \\
\hline R-Square: Within & & .6537 & & 6470 & & .7347 \\
\hline R-Square: Between & & .0879 & & .0840 & & .9151 \\
\hline R-Square: Overall & & .2085 & & .1613 & & .6807 \\
\hline No. of Observations & & 4129 & & 3562 & & 628 \\
\hline No. of Countries & & 27 & & 23 & & 4 \\
\hline
\end{tabular}

Note: OECD includes all the OECD countries except Japan and Korea. OECD_LDC includes Hungary, Mexico, Poland, and Turkey. OECD_DC includes OECD but excludes OECD_LDC. 
Table 6: Error Correction Model for the Asia Sample

\begin{tabular}{|c|c|c|c|c|c|c|}
\hline \multirow[t]{2}{*}{$\begin{array}{l}\text { Dependent variable: } \\
\Delta \mathrm{EX}\end{array}$} & \multicolumn{2}{|r|}{$\begin{array}{r}\text { Asia } \\
(1)\end{array}$} & \multicolumn{2}{|c|}{$\begin{array}{c}\text { Asia_DC } \\
(2)\end{array}$} & \multicolumn{2}{|c|}{$\begin{array}{c}\text { Asia_LDC } \\
(3) \\
\end{array}$} \\
\hline & Coeff. & $\begin{array}{c}\text { Standard } \\
\text { Error }\end{array}$ & Coeff. & $\begin{array}{c}\text { Standard } \\
\text { Error }\end{array}$ & Coeff. & $\begin{array}{c}\text { Standard } \\
\text { Error }\end{array}$ \\
\hline ERROR Correction & -0.09 & $(0.01)^{* * *}$ & -0.24 & $(0.02)^{* * *}$ & -0.06 & $(0.02)^{* * *}$ \\
\hline$\triangle$ GDP_OECD & 0.59 & $(0.30)^{* *}$ & 1.87 & $(0.38)^{* *}$ & -0.42 & $(0.43)$ \\
\hline$\Delta$ GDP_XOECD & 1.65 & $(0.20)^{* * *}$ & 1.18 & $(0.25)^{* * *}$ & 2.08 & $(0.28)^{* * *}$ \\
\hline$\Delta$ EER_volatility & -0.13 & $(0.05)^{* * *}$ & 0.08 & $(0.08)$ & -0.29 & $(0.06)^{* * *}$ \\
\hline$\Delta \mathrm{EER}$ & -0.06 & $(0.02)^{* * *}$ & 0.03 & $(0.04)$ & -0.14 & $(0.03)^{* * *}$ \\
\hline$\Delta \mathrm{FDI}$ & -0.51 & $(0.37)$ & -2.29 & $(0.55)^{* * *}$ & -0.64 & $(0.49)$ \\
\hline Crisis1997 & -0.02 & $(0.004)^{* * *}$ & -0.02 & $(0.005)^{* * *}$ & -0.01 & $(0.01)^{* * *}$ \\
\hline Crisis1997_SQ/100 & 0.08 & $(0.02)^{* * *}$ & 0.12 & $(0.03)^{* * *}$ & 0.04 & $(0.03)$ \\
\hline Crisis2001 & -0.05 & $(0.003)^{* * *}$ & -0.06 & $(0.004)^{* * *}$ & -0.05 & $(0.004)^{* * *}$ \\
\hline Crisis2001_SQ/100 & 0.30 & $(0.02)^{* * *}$ & 0.33 & $(0.02)^{* * *}$ & 0.26 & $(0.02)^{* * *}$ \\
\hline Crisis2008 & -0.09 & $(0.01)^{* * *}$ & -0.07 & $(0.01)^{* * *}$ & -0.11 & $(0.01)^{* * *}$ \\
\hline Crisis2008_SQ/100 & 0.60 & $(0.04)^{* * *}$ & 0.47 & $(0.05)^{* * *}$ & 0.69 & $(0.06)^{* * *}$ \\
\hline constant & 0.03 & $(0.01)^{* *}$ & 0.01 & $(0.02)^{*}$ & 0.04 & $(0.02)^{* * *}$ \\
\hline R-Square: Within & & 0.7368 & & 8385 & & .6966 \\
\hline R-Square: Between & & 0.0050 & & 4012 & & .6526 \\
\hline R-Square: Overall & & 0.5696 & & 6020 & & .5159 \\
\hline No. of Observations & & 1470 & & 594 & & 876 \\
\hline No. of Countries & & 10 & & 4 & & 6 \\
\hline
\end{tabular}


Table 7: Error Correction Model for the Asia Sample by Manufacturing Group

\begin{tabular}{|c|c|c|c|c|}
\hline \multirow[t]{2}{*}{ Dependent variable: $\Delta \mathrm{EX}$} & \multicolumn{2}{|r|}{$\begin{array}{l}\text { Group A } \\
\text { (1) }\end{array}$} & \multicolumn{2}{|c|}{$\begin{array}{l}\text { Group B } \\
\text { (2) }\end{array}$} \\
\hline & Coeff. & $\begin{array}{c}\text { Standard } \\
\text { Error } \\
\end{array}$ & Coeff. & $\begin{array}{c}\text { Standard } \\
\text { Error }\end{array}$ \\
\hline ERROR Correction & -0.11 & $(0.01)^{* * *}$ & -0.24 & $(0.02)^{* * *}$ \\
\hline$\Delta$ GDP_OECD & 3.36 & $(0.42)^{* * *}$ & -0.51 & $(0.38)$ \\
\hline$\Delta$ GDP_XOECD & 0.94 & $(0.32)^{* * *}$ & 3.05 & $(0.29)^{* * *}$ \\
\hline$\Delta$ EER_volatility & -0.55 & $(0.07)^{* * *}$ & -0.03 & $(0.06)$ \\
\hline$\Delta \mathrm{EER}$ & 0.07 & $(0.03)^{*}$ & -0.08 & $(0.03)^{* *}$ \\
\hline$\Delta \mathrm{FDI}$ & 0.19 & $(0.35)$ & 1.61 & $(0.33)^{* * *}$ \\
\hline Crisis1997 & 0.003 & $(0.01)$ & -0.01 & $(0.01)^{*}$ \\
\hline Crisis1997_SQ/100 & -0.03 & $(0.04)$ & 0.03 & $(0.04)$ \\
\hline Crisis2001 & -0.05 & $(0.005)^{* * *}$ & -0.04 & $(0.004)^{* * *}$ \\
\hline Crisis2001_SQ/100 & 0.30 & $(0.03)^{* * *}$ & 0.19 & $(0.03)^{* * *}$ \\
\hline Crisis2008 & -0.03 & $(0.01)^{* * *}$ & -0.08 & $(0.01)^{* * *}$ \\
\hline Crisis2008_SQ/100 & 0.23 & $(0.05)^{* * *}$ & 0.49 & $(0.04)^{* * *}$ \\
\hline constant & -0.02 & $(0.02)$ & -0.04 & $(0.02)^{* *}$ \\
\hline R-Square: Within & & 0.5336 & & 6329 \\
\hline R-Square: Between & & 0.0154 & & 036 \\
\hline R-Square: Overall & & 0.3255 & & 3070 \\
\hline No. of Observations & & 1369 & & 369 \\
\hline No. of Countries & & 9 & & 9 \\
\hline
\end{tabular}

Note: Group A includes electronics, machinery, electrical equipment, ICT, transportation, and precision instruments. Group B includes textiles, apparel, plywood product, paper, furniture, rubbers and plastics, metal products, nonmetal products, basic metal, printing, chemical materials, chemical products, and petroleum. 
Table 8: Number of Months to Bottom Out

\begin{tabular}{lccc}
\hline & 1997 & 2001 & 2008 \\
\hline Full Sample & - & 9.97 & 8.24 \\
OECD Countries: & - & 10.74 & 8.37 \\
OECD_DC & - & 10.68 & 8.43 \\
OECD_LDC & - & 11.72 & 8.17 \\
G6 & - & 11.48 & 8.45 \\
Asian Countries: & 11.71 & 9.07 & 7.69 \\
Asia_DC & 10.44 & 9.23 & 7.46 \\
Asia_LDC & 15.08 & 8.96 & 7.75 \\
Group A & 4.91 & 8.37 & 6.67 \\
Group B & 15.97 & 10.58 & 8.43 \\
\hline
\end{tabular}

Source: The author's calculation. 
Table 9 Export Orders and Inventory for P\&C and ICT Industries in Taiwan

\begin{tabular}{|c|c|c|c|c|}
\hline & \multicolumn{2}{|c|}{$\begin{array}{c}\text { Upstream Industry } \\
\text { (Electronic Parts and Component) }\end{array}$} & \multicolumn{2}{|c|}{$\begin{array}{l}\text { Downstream Industry } \\
\text { (Computers, Electronic } \\
\text { \& Optical Products) }\end{array}$} \\
\hline & Order & Inventory & Order & Inventory \\
\hline 2000 & 54.05 & 31.09 & 17.88 & 18.42 \\
\hline 2001 & -23.64 & 24.84 & -12.31 & 8.84 \\
\hline 2002 & 11.33 & -15.05 & 24.46 & 25.45 \\
\hline 2003 & 16.54 & 14.60 & 15.98 & -22.24 \\
\hline 2004 & 38.76 & 20.67 & 15.12 & 14.68 \\
\hline 2005 & 21.60 & 26.31 & 24.52 & 16.89 \\
\hline 2006 & 20.35 & 16.29 & 23.04 & -14.30 \\
\hline 2007 & 15.46 & 3.96 & 21.41 & 9.40 \\
\hline 2008 M01 & 16.28 & 6.74 & 7.62 & 0.45 \\
\hline M02 & 22.79 & 13.18 & 3.52 & 5.36 \\
\hline M03 & 15.10 & 18.70 & 8.04 & 7.83 \\
\hline M04 & 18.07 & 21.70 & 19.71 & 12.6 \\
\hline M05 & 17.91 & 28.06 & 17.64 & 17.13 \\
\hline M06 & 9.83 & 24.69 & 11.97 & 10.11 \\
\hline M07 & 8.60 & 30.99 & 15.74 & 10.86 \\
\hline M08 & 4.22 & 43.37 & 12.08 & 3.54 \\
\hline M09 & 3.18 & 55.15 & 10.61 & 2.27 \\
\hline M010 & -1.73 & 46.97 & 11.9 & 0.17 \\
\hline M011 & -27.7 & 58.41 & -11.52 & 2.86 \\
\hline M012 & -30.84 & 39.55 & -23.14 & 3.62 \\
\hline 2009 M01 & -38.85 & 31.19 & -30.47 & 6.78 \\
\hline M02 & -22.33 & 21.55 & -10.57 & 0.74 \\
\hline M03 & -16.60 & 13.24 & -18.56 & -3.24 \\
\hline M04 & -14.76 & 7.32 & -16.25 & -10.49 \\
\hline M05 & -11.33 & 4.27 & -11.90 & -6.58 \\
\hline M06 & -6.12 & 1.15 & 2.87 & -4.04 \\
\hline M07 & -7.97 & -4.16 & -3.64 & -1.88 \\
\hline M08 & -12.2 & -13.08 & -9.07 & -1.86 \\
\hline M09 & -0.24 & -15.42 & 2.41 & -1.12 \\
\hline M010 & 4.06 & -9.58 & 5.64 & -0.83 \\
\hline M011 & 43.23 & -13.03 & 33.91 & -3.93 \\
\hline M012 & 53.08 & -9.03 & 61.53 & -8.85 \\
\hline
\end{tabular}

Source: Calculated from Yearbook of Industrial Production Statistics, Taiwan Area, the Republic of China, complied by Department of Statistics, Ministry of Economic Affairs, various issues. 
Figure 1: Export Growth 1995-2010 - OECD Countries; \%

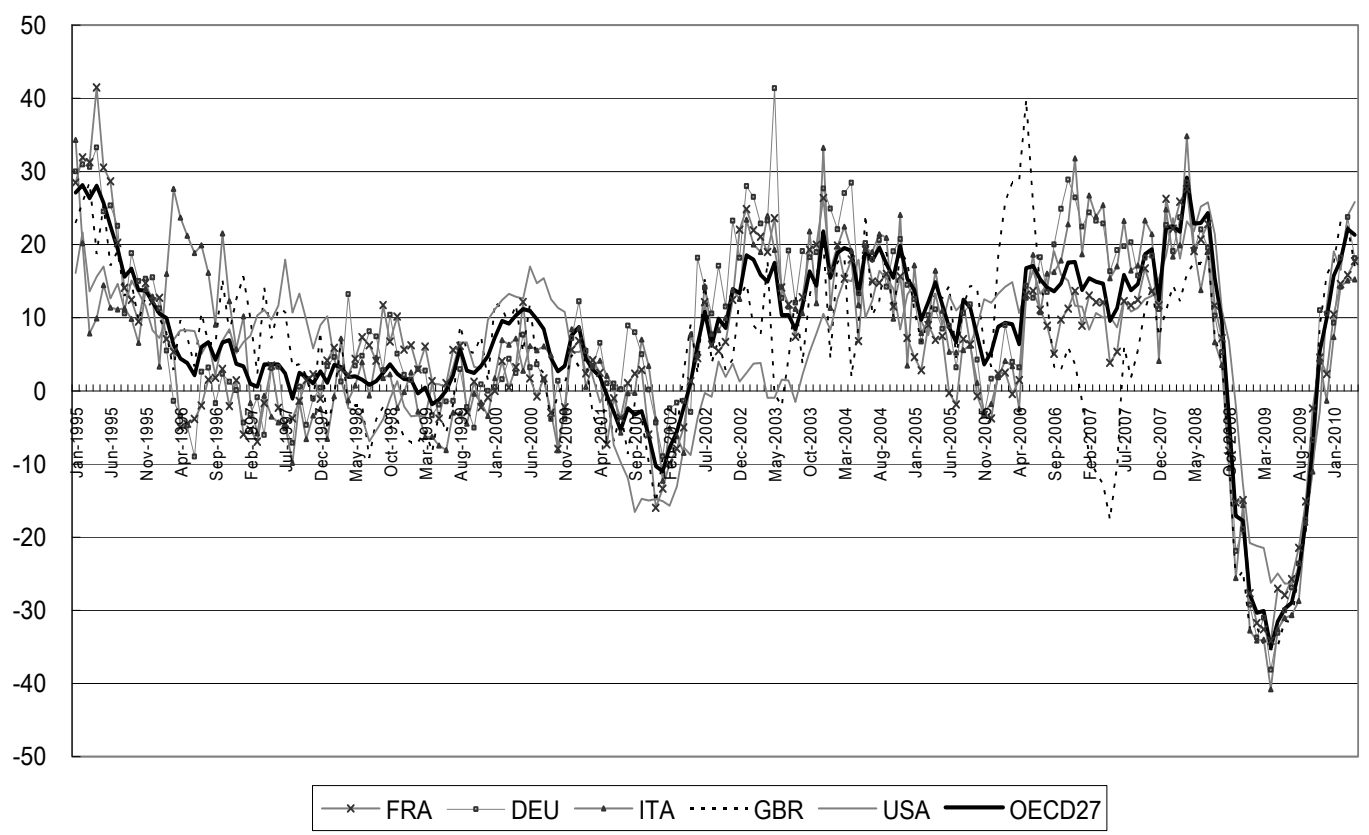

Figure 2: Export Growth 1995-2010 - Asian Countries; \%

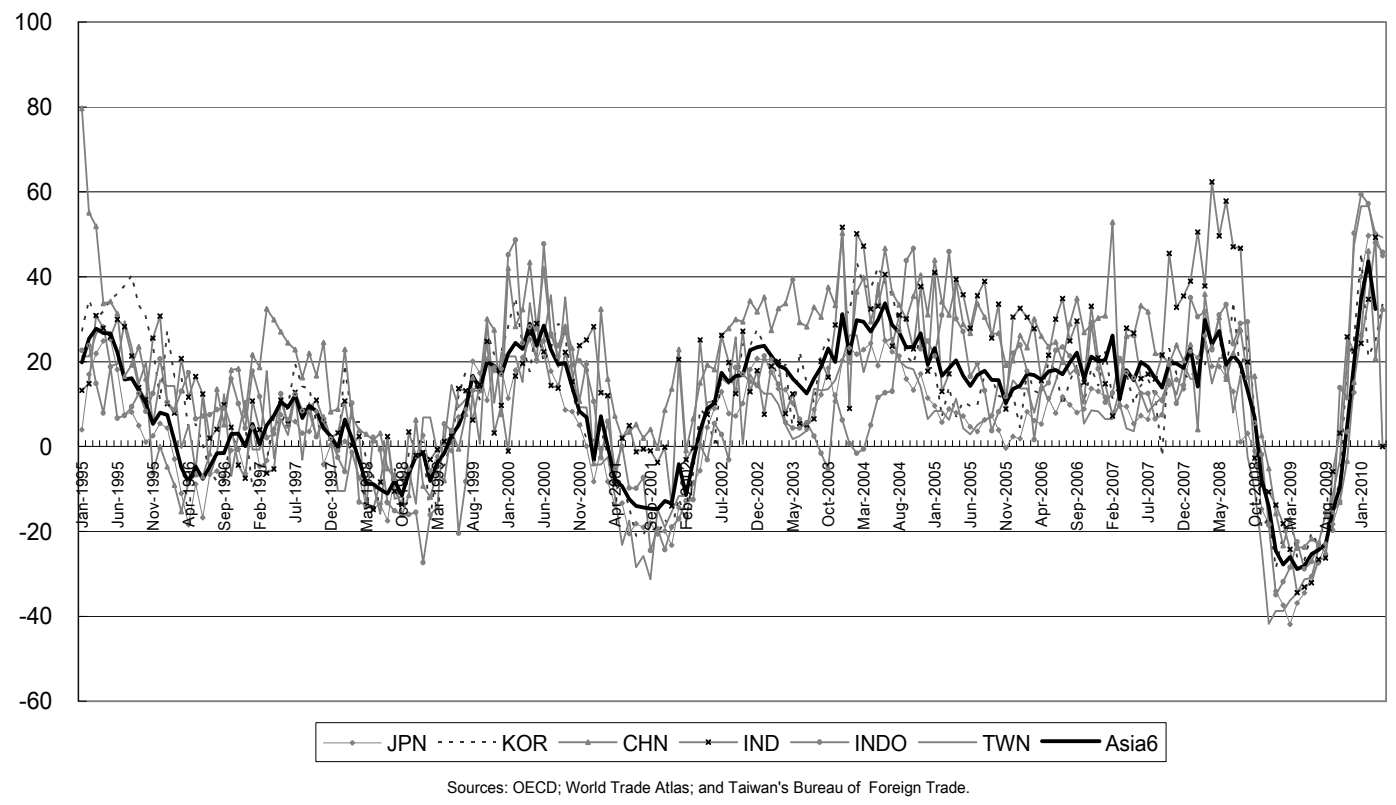

